\title{
Photodegradation Study of Toluidine Blue Dye in Aqueous Solution using Magnesium Oxide as a Photocatalyst
}

\author{
Haydar A. Mohammad Salim ${ }^{1}$, Sabir Ayob Mohammad Salih ${ }^{1}$ \\ ${ }^{1}$ Dept. of Chemistry, Faculty of Science, University of Zakho, Kurdistan Region-Iraq \\ Correspondence: Haydar A. Mohammad Salim, Dept. of Chemistry, Faculty of Science, University of Zakho, \\ Kurdistan Region-Iraq. E-mail: Haydar.kovly@gmail.com
}

Received: September 6, 2015

Accepted: September 21, 2015 Online Published: Octobe16, 2015

doi:10.5539/ijc.v7n2p143

URL: http://dx.doi.org/10.5539/ijc.v7n2p143

\begin{abstract}
The photocatalytic degradation of Toluidine Blue dye (TB) in aqueous solution was investigated under UV light in the presence of magnesium oxide $(\mathrm{MgO})$ as a photocatalyst at different operating parameters. The operating conditions were photocatalyst dose, initial dye concentration and the $\mathrm{pH}$ of the solution. Increasing of photocatalyst dose from 10 to $70 \mathrm{mg}$ enhanced the degradation rate of TB dye. However, the increasing of TB dye concentration from 2 to $8 \mathrm{mg} / \mathrm{L}$ negatively affected the degradation rate. It was found that the percent of dye removal reached the maximum value at high acidic medium. In dark condition, $15 \%$ of dye was adsorbed by $\mathrm{MgO}$. Furthermore, the kinetics involved in the degradation of TB dye was examined and the degradation was found to follow pseudo first order kinetic model.
\end{abstract}

Keywords: Photocatalyst, MgO, Toluidine Blue, Kinetic, Dye, AOPs

\section{Introduction}

Textile industries consume large amount of water and produce large volume of dye effluents, in deferent steps in the dyeing and finishing processes, which are non-biodegradable and toxic (Reife \& Freeman, 1996). These dye effluents are often rich in colour, containing reactive dyes and chemicals and create several environmental problems by discharging into the aqueous phase. Various physical and chemical processes such as reverse osmosis, adsorption, precipitation, ultrafiltration, flocculation and air stripping can be used for removal of colour from dye effluents (Georgiou, Melidis, Aivasidis, \& Gimouhopoulos, 2002; Ledakowicz, Solecka, \& Zylla, 2001; Peralta-Zamora et al., 1999; Robinson, McMullan, Marchant, \& Nigam, 2001). These techniques, however, are non-destructive because they only transfer pollutants into sludge, which needs further treatment (Arslan, Balcioglu, Tuhkanen, \& Bahnemann, 2000; Chaudhuri \& Sur, 2000; Stock, Peller, Vinodgopal, \& Kamat, 2000).

Recent interest in advanced oxidation processes (AOPs) has considerably increased for the complete degradation of dyes. These processes are based on generation of hydroxyl radicals that react with a broad range of organic contaminants rapidly and non-selectively (Das, Kamat, Padmaja, Au, \& Madison, 1999; Yang, Wyatt Ii, \& Bahorsky, 1998). AOPs include photocatalytic systems such as combination of light and semiconductors, and oxidants with semiconductor. Heterogeneous photocatalytic has emerged as a significant destructive technology leading to the total mineralization of most of the organic contaminants including organic dyes (Galindo, Jacques, \& Kalt, 2001; Khodja, Sehili, Pilichowski, \& Boule, 2001; Kusvuran, Samil, Atanur, \& Erbatur, 2005; Neppolian, Choi, Sakthivel, Arabindoo, \& Murugesan, 2002).

Titanium dioxide $\left(\mathrm{TiO}_{2}\right)$ is characterized by non-toxicity, cheap production cost and chemical stability, therefore it represents one of the most important oxides that used in various fields of photochemistry, for instance, in photoelectrolysis of water, environmental remediation, and dye-sensitized solar cells (Anpo, 2004; Cappelletti et al., 2009; Chen \& Mao, 2007; Gratzel, 2001). Furthermore, the Fenton process is being increasingly used in the treatment of textile industries (Bautista, Mohedano, Gilarranz, Casas, \& Rodriguez, 2007; Lofrano, Meriç, Belgiorno, Nikolaou, \& Napoli, 2007; Meriç, Lofrano, \& Belgiorno, 2005). Among AOPs, homogeneous photocatalysis using UV with hydrogen peroxide, $\mathrm{H}_{2} \mathrm{O}_{2}$, have received a great attention in degrading or reducing organic pollutant by generation of two molecules of hydroxyl radicals (Al-Ekabi, Safarzadeh-Amiri, Sifton, \& Story, 1991; Chu, Lau, \& Fung, 2006; Saien, Ojaghloo, Soleymani, \& Rasoulifard, 2011). In some cases, a combination of various treatment processes is needed to improve the overall efficiency of the water treatment systems and to optimize economic requirements (Oller, Malato, \& Sánchez-Pérez, 2011; Parrino, Camera-Roda, 
Loddo, Palmisano, \& Augugliaro, 2014; Rueda-Márquez, Pintado-Herrera, Martín-Díaz, Acevedo-Merino, \& Manzano, 2015).

Although $\mathrm{TiO}_{2}$ and $\mathrm{ZnO}$ well known metal oxides for AOPs and have higher band gap than MgO, however; $\mathrm{MgO}$ is less expensive and commercially available (Khan, Adil, \& Al-Mayouf, 2015; Raza, Haque, Muneer, \& Bahnemann). The aim of this study was to present the photocatalytic degradation of Toluidine Blue (TB) dye in aqueous solution using $\mathrm{MgO}$ as a photocatalyst under various operating conditions. The operating conditions were $\mathrm{MgO}$ quantity, $\mathrm{TB}$ concentration and $\mathrm{pH}$ of the solution. The adsorption and kinetic study of $\mathrm{TB}$ on $\mathrm{MgO}$ surface were also studied.

\section{Method}

\subsection{Materials}

Toluidine blue (TB) dye was purchased from Labpak Chemicals Ltd, UK, and used as received to prepare solutions that used in this research. Table 1 shows the characteristics of TB dye. A stock solution of TB (1000 $\mathrm{mg} / \mathrm{L})$ was prepared using deionized water and other concentrations $(2,4,6$ and $8 \mathrm{mg} / \mathrm{L})$ were prepared by dilution the stock solution of TB. The stock solution of TB $(1000 \mathrm{mg} / \mathrm{L})$ was covered and stored in a dark place. Magnesium oxide (MgO) was purchased from ROTH, Germany, and used as received without any modification and used as photocatalyst in this study. Sodium carbonate and ethanol were purchased from Fisher-Scientific, UK. Nitric acid $\left(\mathrm{HNO}_{3}\right)$ and sodium hydroxide $(\mathrm{NaOH})$ were purchased from Fisher-Scientific, UK. Various molarities of $\mathrm{HNO}_{3}$ and $\mathrm{NaOH}$ were used to adjust the $\mathrm{pH}$ value of solutions between 2 and 12 using pH meter. The $\mathrm{pH}$ of the solution was determined using $\mathrm{pH}$ meter (EUTECH, Malaysia). UV lamp with $254 \mathrm{~nm}$ (12 watt) was purchased from SEMTEC, China. Visible spectrophotometer (Jenway, 6700) was used to analyse the collected samples.

Table 1. Characteristics of TB dye

C.I. index
Chemical Name
Chemical Formula
Molecular Mass
Molecular structure

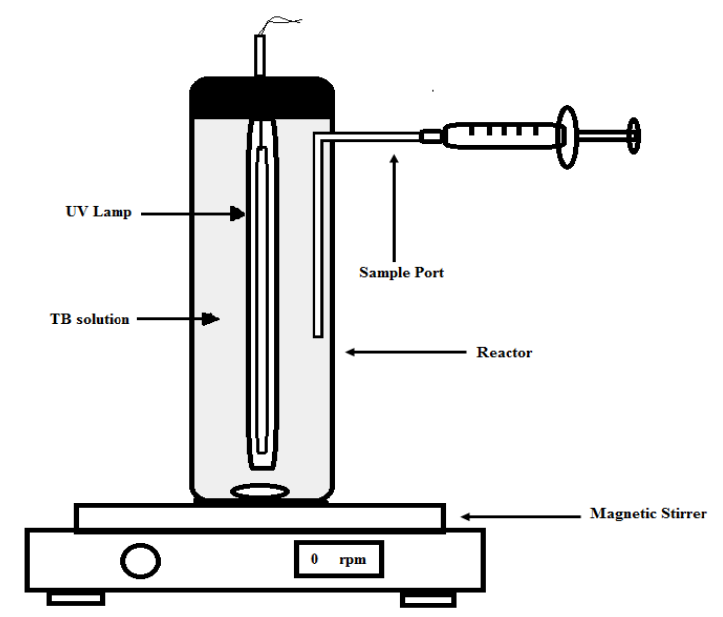

Figure 1. Photocatalytic Reactor Design

\subsection{Experimental Procedure}

A closed reactor with a volume of $600 \mathrm{~mL}$ was used in this research as shown in Figure 1. At a specific concentration of TB solution, $500 \mathrm{~mL}$ of solution was charged into a reactor. $\mathrm{MgO}$ with a specific amount (10, 30,50 and $70 \mathrm{mg}$ ) was added to TB solution as a photocatalyst. The volume of the reactor was $600 \mathrm{~mL}$. It is 
made from PYREX glass and fitted with a sample port. The reactor was equipped with a plunging tube in which a SEMTEC 12 watt lamp was placed horizontally. A glass syringe with $5 \mathrm{~mL}$ volume was used, at a specific schedule, to collect samples. The $\mathrm{pH}$ values, from 2 to 12 , of these solutions were adjusted using different molarities of $\mathrm{NaOH}$ and $\mathrm{HNO}_{3}$.

\section{Results and Discussion}

\subsection{Effect of Photocatalyst Dose}

The catalyst dose, in photocatalytic process, is an important parameter since increasing in the amount of photocatlyst increased the active sites number on the photocatalyst causing generation more $\mathrm{OH}^{*}$ radicals (Nishio, Tokumura, Znad, \& Kawase, 2006). The degradation of TB was studied in the semi-batch reactor. A $500 \mathrm{~mL}$ volume of TB solution with the concentration of $4 \mathrm{mg} / \mathrm{L}$ were charged in the reactor with different amount of $\mathrm{MgO}(10,30,50$ and $70 \mathrm{mg})$. As shown in Figure 2, the concentration of TB reduced with time. It also shows that the increasing of $\mathrm{MgO}$ amount increases the removal efficiency. This is due to the formation of highest amount of hydroxyl radical when more amount of $\mathrm{MgO}$ was used. The degradation of $\mathrm{TB}$ reaches maximum value when $50 \mathrm{mg}$ of $\mathrm{MgO}$ was used in $70 \mathrm{~min}$ of reaction time. A further increase in the catalyst dose does not affect the removal efficiency of TB dye. This is due to the blocking of UV light penetration with increasing photocatalyst amount (Saquib, Abu Tariq, Haque, \& Muneer, 2008).

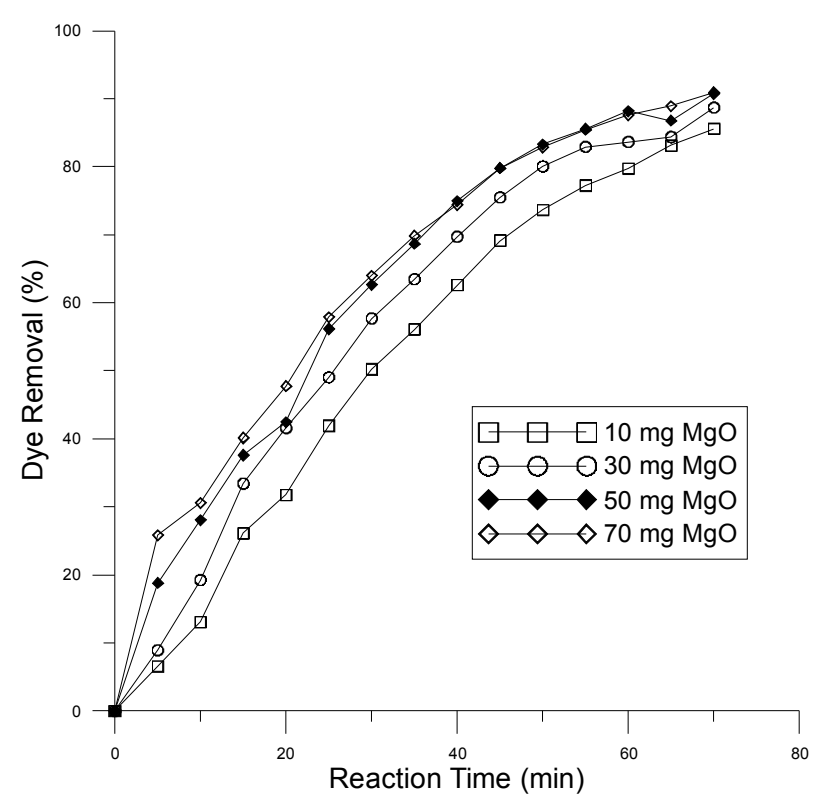

Figure 2. Effect of Photocatalyst Dose $\left([\mathrm{TB}]_{0}=4 \mathrm{mg} / \mathrm{L}\right.$, Volume $\left.=500 \mathrm{~mL}, \mathrm{pH}=4\right)$

\subsection{Effect of Initial TB Concentration}

The influence of the initial concentration of TB dye on its photocatalytic degradation rate was studied for $(2,4,6$ and $8 \mathrm{mg} / \mathrm{L}$ ) using $50 \mathrm{mg}$ of $\mathrm{MgO}$. The results show that increasing the initial concentration of TB reduced the degradation rate (see Figure 3). As shown in Figure 3, when TB concentration increased from 10 to $70 \mathrm{mg} / \mathrm{L}$, the removal percentage of TB at $70 \mathrm{~min}$ of reaction time decreased from $95 \%$ to $81 \%$, respectively. The results presented in this study are in agreement with the previous study for other dyes such as Reactive Orange 5, methylene blue and Mercurochrome dyes when MgO used as a photocatalyst (Bandara \& Ranasinghe, 2007; Kamel, Mashaly, \& Abdelghaffar, 2013; Xiang, Xie, Li, \& Li, 2013). The deeper colour of TB solution, at high concentration, would not be high transparent to UV light as in low concentration of dye and a significant amount of UV light would be absorbed by the TB molecules causing less light to reach $\mathrm{MgO}$ particle. Hence, the formation of $\mathrm{OH}^{*}$ radicals reduced. The rate constant, $\mathrm{k}$, was found to decrease linearly with increased initial TB concentration. The photodegradation of $\mathrm{TB}$ dye on the surface of $\mathrm{MgO}$ catalyst follows pseudo first order kinetic law and, expressed as follows:

$$
\ln \left(\mathrm{C} / \mathrm{C}_{\mathrm{o}}\right)=-\mathrm{k}^{\prime} \mathrm{t}
$$




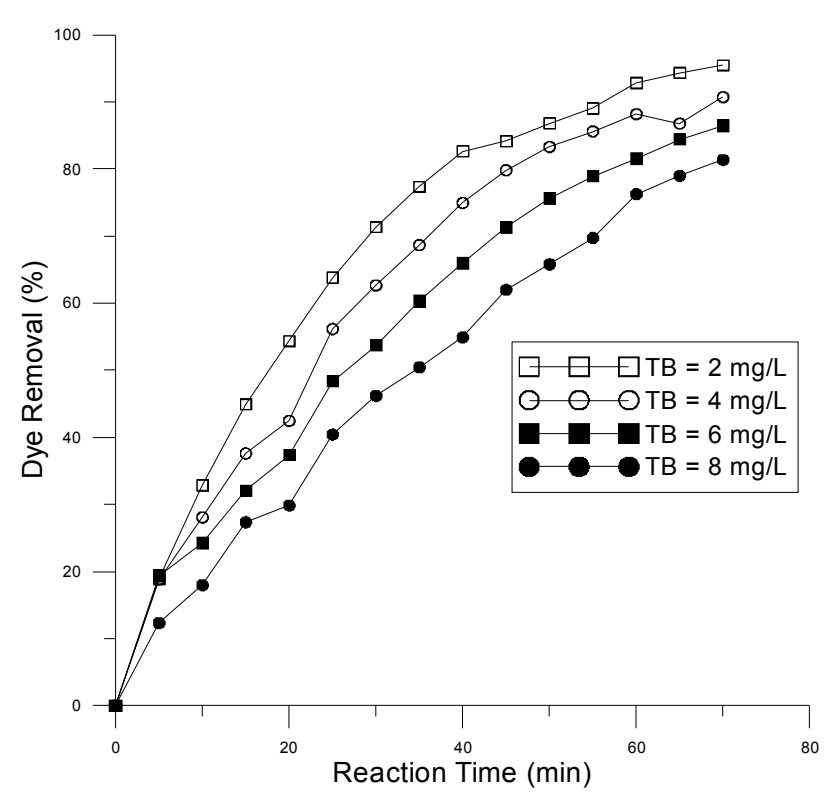

Figure 3. Effect of initial TB concentration $(\mathrm{MgO}=50 \mathrm{mg} / \mathrm{L}$, Volume $=500 \mathrm{~mL}, \mathrm{pH}=4)$

Where $\mathrm{C}_{\mathrm{o}}$ and $\mathrm{C}$ are the dye concentration at $\mathrm{t}=0$ and $\mathrm{t}=\mathrm{t}$, respectively, $\mathrm{k}$ ' is the rate constant. The plot of the experimental data (ln $\mathrm{C} / \mathrm{C}_{\mathrm{o}}$ against $\mathrm{t}$ ) yielding to a straight line, as shown in Figure 4, with relatively high regression coefficients $\left(\mathrm{R}^{2}\right)$. The kinetic parameters of photocatalytic degradation of TB by $\mathrm{MgO}$ in aqueous solution at various initial TB concentrations were recorded in Table 2.

Table 2. Kinetic parameters of photocatalytic degradation of TB as a function of initial TB concentration

\begin{tabular}{cccc}
\hline TB concentration $(\mathrm{mg} / \mathrm{L})$ & $\mathrm{k}^{\prime}$ & $\mathrm{R}^{2}$ & Dye Removal \% \\
\hline 2 & 0.0437 & 0.9951 & 95.5 \\
4 & 0.0343 & 0.9901 & 90.7 \\
6 & 0.0285 & 0.9953 & 86.4 \\
8 & 0.0238 & 0.9868 & 81.4 \\
\hline
\end{tabular}

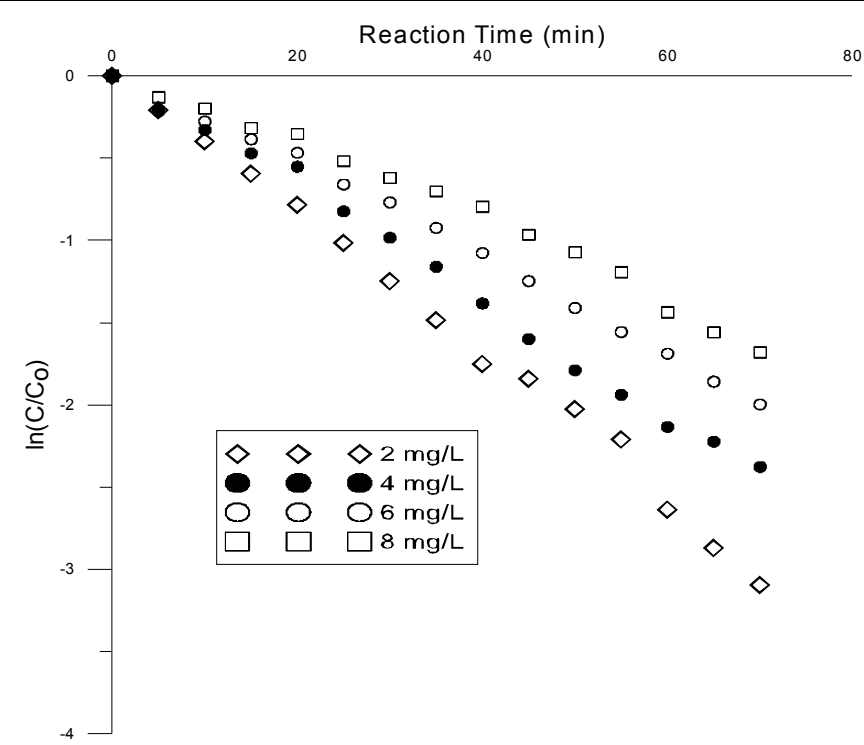

Figure 4. Pseudo first order kinetics of photocatalytic degradation of TB as a function of initial TB concentration $(\mathrm{MgO}=50 \mathrm{mg} / \mathrm{L}$, Volume $=500 \mathrm{~mL}, \mathrm{pH}=4)$.

\subsection{Effect of $p H$}

A series of experiments were performed at various $\mathrm{pH}$ values to test the $\mathrm{pH}$ effect on photocatalytic degradation of TB dye. Figure 5 illustrated the removal percent of TB in aqueous solution at different $\mathrm{pH}$ solutions. As shown from the figure, the initial $\mathrm{pH}$ of solution plays an important role in controlling the removal of TB dye using $\mathrm{MgO}$. The $\mathrm{pH}$ effect was studied in the range 2-12. Since TB has two pKa values (2.4 and 11.6) (Sabnis, 2010), 
see Figure 5, the degradation rate increases in high acidic and high basic medium. The photodegradation was significantly enhanced at low $\mathrm{pH}$ values, while at high $\mathrm{pH}$ values insignificantly enhanced. The removal percent reached maximum value in high acidic medium with a value of $92 \%$; however, removal percent reached minimum value at $\mathrm{pH} 8$ with a value of approximately $60 \%$.

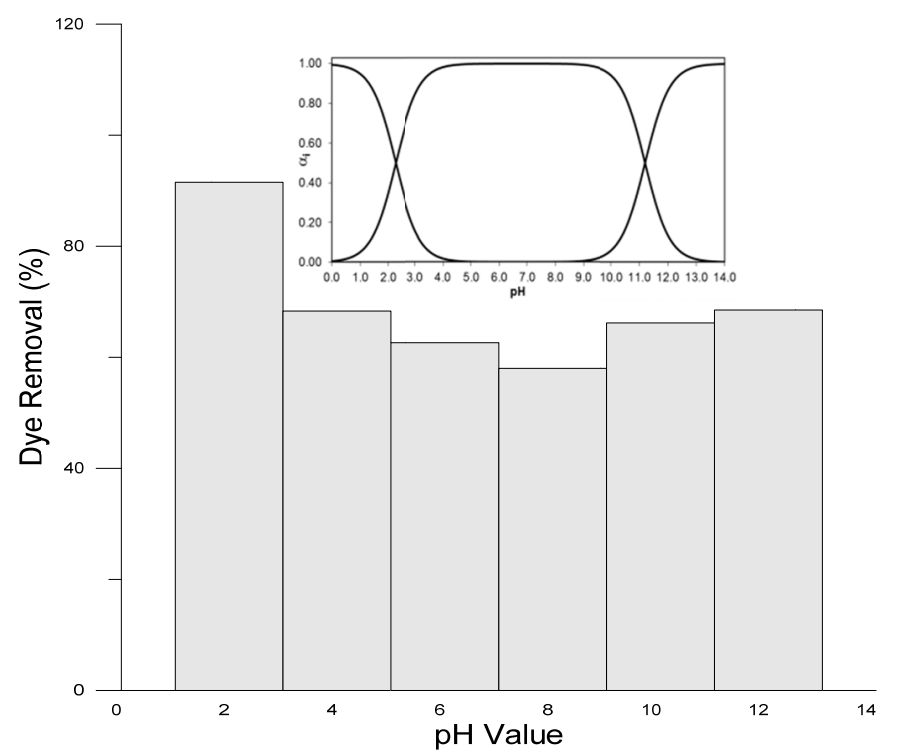

Figure 5. Effect of $\mathrm{pH}\left([\mathrm{TB}]_{\mathrm{o}}=4 \mathrm{mg} / \mathrm{L}, \mathrm{MgO}=50 \mathrm{mg} / \mathrm{L}\right.$, Volume $\left.=500 \mathrm{~mL}\right)$

\subsection{Adsorption of TB on $\mathrm{MgO}$ Surface}

The TB adsorption on $\mathrm{MgO}$ was obtained at $20{ }^{\circ} \mathrm{C}, \mathrm{pH} 4$ and constant shaker under dark conditions. The experiment was performed with $200 \mathrm{~mL}$ of TB dye with $4 \mathrm{mg} / \mathrm{L}$ and $50 \mathrm{mg}$ of $\mathrm{MgO}$. As Shown in Figure 6 , around $14 \%$ of TB dye was removed from $\mathrm{MgO}$ surface at $80 \mathrm{~min}$ of adsorption time.

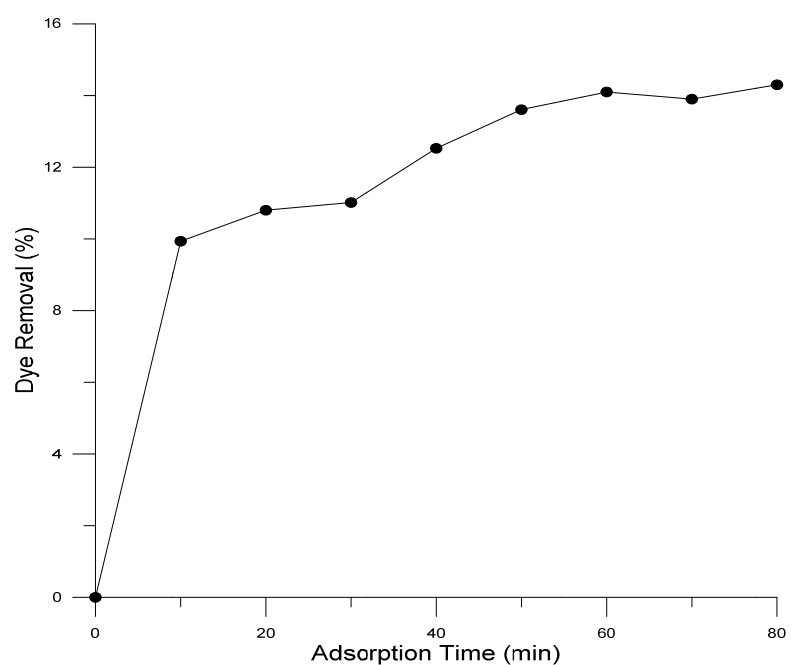

Figure 6. Adsorption of TB on $\mathrm{MgO}$ surface $(\mathrm{MgO}=50 \mathrm{mg} / \mathrm{L}$, Volume $=500 \mathrm{~mL}, \mathrm{pH}=4)$

\section{Conclusion}

Toluidine Blue dye was degraded in aqueous solution under UV light in the presence of $\mathrm{MgO}$ as a photocatalyst. The degradation of TB was conducted at different operating parameters including TB concentration, $\mathrm{MgO}$ dose and $\mathrm{pH}$ of the solution. The most effective improvements on the degradation of TB were recorded with initial TB concentration of $2 \mathrm{mg} / \mathrm{L}$. It was also found that the increasing of $\mathrm{MgO}$ quantity enhanced the reaction rate of $\mathrm{TB}$ removal. The removal efficiency of TB was favorable in the high acidic medium and reached the maximum value. The degradation of TB at different initial dye concentration follows the pseudo first order kinetics.

\section{References}

Al-Ekabi, H., Safarzadeh-Amiri, A., Sifton, W., \& Story, J. (1991). Advanced technology for water purification by heterogeneous photocatalysis. International Journal of Environment and Pollution, 1(1-2), 125-13. 
Anpo, M. (2004). Preparation, characterization, and reactivities of highly functional titanium oxide-based photocatalysts able to operate under UV-visible light irradiation: Approaches in realizing high efficiency in the use of visible light. Bulletin of the Chemical Society of Japan, 77(8), 1427-1442. http://dx.doi.org/ 10.1246/bcsj.77.1427

Arslan, I., Balcioglu, I. A., Tuhkanen, T., \& Bahnemann, D. (2000). $\mathrm{H}_{2} \mathrm{O}_{2} / \mathrm{UV}-\mathrm{C}$ and $\mathrm{Fe}^{2+} / \mathrm{H}_{2} \mathrm{O}_{2} / \mathrm{IV}-\mathrm{C}$ versus $\mathrm{TiO}_{2} / \mathrm{UV}-\mathrm{A}$ treatment for reactive dye wastewater. Journal of Environmental Engineering, 126(10), 903-911. http://dx.doi.org/ 10.1061/(ASCE)0733-9372(2000)126:10(903)

Bandara, J., \& Ranasinghe, R. A. S. S. (2007). The effect of $\mathrm{MgO}$ coating on photocatalytic activity of $\mathrm{SnO}_{2}$ for the degradation of chlorophenol and textile colorants; the correlation between the photocatalytic activity and the negative shift of flatband potential of $\mathrm{SnO}_{2}$. Applied Catalysis A: General, 319, 58-63. http://dx.doi.org/10.1016/j.apcata.2006.11.013

Bautista, P., Mohedano, A. F., Gilarranz, M. A., Casas, J. A., \& Rodriguez, J. J. (2007). Application of Fenton oxidation to cosmetic wastewaters treatment. Journal of Hazardous Materials, 143(1-2), 128-134. http://dx.doi.org/ 10.1016/j.jhazmat.2006.09.004

Cappelletti, G., Ardizzone, S., Bianchi, C. L., Gialanella, S., Naldoni, A., Pirola, C., \& Ragaini, V. (2009). Photodegradation of pollutants in air: Enhanced properties of nano- $\mathrm{TiO}_{2}$ prepared by ultrasound. Nanoscale Research Letters, 4(2), 97-105. http://dx.doi.org/10.1007/s11671-008-9208-3

Chaudhuri, S. K., \& Sur, B. (2000). Oxidative decolorization of reactive dye solution using fly ash as catalyst. Journal of Environmental Engineering, 126(7), 583-594. http://dx.doi.org/ 10.1061/(ASCE)0733-9372(2000)126:7(583)

Chen, X., \& Mao, S. S. (2007). Titanium dioxide nanomaterials: Synthesis, properties, modifications and applications. Chemical Reviews, 107(7), 2891-2959. http://dx.doi.org/ 10.1021/cr0500535

Chu, W., Lau, T. K., \& Fung, S. C. (2006). Effects of combined and sequential addition of dual oxidants (H 2O2/S2O8 2-) on the aqueous carbofuran photodegradation. Journal of Agricultural and Food Chemistry, 54(26), 10047-10052. http://dx.doi.org/ 10.1021/jf062018k

Das, S., Kamat, P. V., Padmaja, S., Au, V., \& Madison, S. A. (1999). Free radical induced oxidation of the azo dye Acid Yellow 9. Journal of the Chemical Society. Perkin Transactions 2(6), 1219-1223.

Galindo, C., Jacques, P., \& Kalt, A. (2001). Photochemical and photocatalytic degradation of an indigoid dye: A case study of acid blue 74 (AB74). Journal of Photochemistry and Photobiology A: Chemistry, 141(1), 47-56.

Georgiou, D., Melidis, P., Aivasidis, A., \& Gimouhopoulos, K. (2002). Degradation of azo-reactive dyes by ultraviolet radiation in the presence of hydrogen peroxide. Dyes and Pigments, 52(2), 69-78. http://dx.doi.org/ 10.1016/S0143-7208(01)00078-X

Gratzel, M. (2001). Photoelectrochemical cells. [10.1038/35104607]. Nature, 414(6861), 338-344.

Kamel, M., Mashaly, H., \& Abdelghaffar, F. (2013). Photocatalyst Decolorization of Reactive Orange 5 Dye Using MgO Nano Powder and $\mathrm{H}_{2} \mathrm{O}_{2}$ Solution. World Applied Sciences Journal, 26(8), 1053-1060.

Khan, M. M., Adil, S. F., \& Al-Mayouf, A. (2015). Metal oxides as photocatalysts. Journal of Saudi Chemical Society, 19(5), 462-464. http://dx.doi.org/10.1016/j.jscs.2015.04.003

Khodja, A. A., Sehili, T., Pilichowski, J. F., \& Boule, P. (2001). Photocatalytic degradation of 2-phenylphenol on $\mathrm{TiO}_{2}$ and $\mathrm{ZnO}$ in aqueous suspensions. Journal of Photochemistry and Photobiology A: Chemistry, 141(2-3), 231-239.

Kusvuran, E., Samil, A., Atanur, O. M., \& Erbatur, O. (2005). Photocatalytic degradation kinetics of di- and tri-substituted phenolic compounds in aqueous solution by $\mathrm{TiO}_{2} / \mathrm{UV}$. Applied Catalysis B: Environmental, 58(3-4), 211-216. http://dx.doi.org/ 10.1016/j.apcatb.2004.11.023

Ledakowicz, S., Solecka, M., \& Zylla, R. (2001). Biodegradation, decolourisation and detoxification of textile wastewater enhanced by advanced oxidation processes. Journal of Biotechnology, 89(2-3), 175-184. http://dx.doi.org/10.1016/S0168-1656(01)00296-6

Lofrano, G., Meriç, S., Belgiorno, V., Nikolaou, A., \& Napoli, R. M. A. (2007). Fenton and photo-Fenton treatment of a synthetic tannin used in leather tannery: A multi-approach study. Water Science and Technology, 55, 53-61. 
Meriç, S., Lofrano, G., \& Belgiorno, V. (2005). Treatment of reactive dyes and textile finishing wastewater using Fenton's oxidation for reuse. International Journal of Environment and Pollution, 23(3), 248-258.

Neppolian, B., Choi, H. C., Sakthivel, S., Arabindoo, B., \& Murugesan, V. (2002). Solar/UV-induced photocatalytic degradation of three commercial textile dyes. Journal of Hazardous Materials, 89(2-3), 303-317. http://dx.doi.org/ 10.1016/S0304-3894(01)00329-6

Nishio, J., Tokumura, M., Znad, H. T., \& Kawase, Y. (2006). Photocatalytic decolorization of azo-dye with zinc oxide powder in an external UV light irradiation slurry photoreactor. Journal of Hazardous Materials, 138(1), 106-115. http://dx.doi.org/10.1016/j.jhazmat.2006.05.039

Oller, I., Malato, S., \& Sánchez-Pérez, J. A. (2011). Combination of Advanced Oxidation Processes and biological treatments for wastewater decontamination-A review. Science of The Total Environment, 409(20), 4141-4166. http://dx.doi.org/10.1016/j.scitotenv.2010.08.061

Parrino, F., Camera-Roda, G., Loddo, V., Palmisano, G., \& Augugliaro, V. (2014). Combination of ozonation and photocatalysis for purification of aqueous effluents containing formic acid as probe pollutant and bromide ion. Water Research, 50(0), 189-199. http://dx.doi.org/10.1016/j.watres.2013.12.001

Peralta-Zamora, P., Kunz, A., de Moraes, S. G., Pelegrini, R., de Campos Moleiro, P., Reyes, J., \& Duran, N. (1999). Degradation of reactive dyes I. A comparative study of ozonation, enzymatic and photochemical processes. Chemosphere, 38(4), 835-852. http://dx.doi.org/10.1016/S0045-6535(98)00227-6

Raza, W., Haque, M. M., Muneer, M., \& Bahnemann, D. (2015). Synthesis of visible light driven $\mathrm{TiO}_{2}$ coated carbon nanospheres for degradation of dyes. Arabian Journal of Chemistry. http://dx.doi.org/10.1016/j.arabjc.2015.09.002

Reife, A., \& Freeman, H. S. (1996). Environmental Chemistry of Dyes and Pigments: Wiley.

Robinson, T., McMullan, G., Marchant, R., \& Nigam, P. (2001). Remediation of dyes in textile effluent: A critical review on current treatment technologies with a proposed alternative. Bioresource Technology, 77(3), 247-255. http://dx.doi.org/ 10.1016/S0960-8524(00)00080-8

Rueda-Márquez, J. J., Pintado-Herrera, M. G., Martín-Díaz, M. L., Acevedo-Merino, A., \& Manzano, M. A. (2015). Combined AOPs for potential wastewater reuse or safe discharge based on multi-barrier treatment (microfiltration- $\mathrm{H}_{2} \mathrm{O}_{2} / \mathrm{UV}$-catalytic wet peroxide oxidation). Chemical Engineering Journal, 270(0), 80-90. http://dx.doi.org/10.1016/j.cej.2015.02.011

Sabnis, R. W. (2010). Handbook of Biological Dyes and Stains: Synthesis and Industrial Applications: Wiley.

Saien, J., Ojaghloo, Z., Soleymani, A. R., \& Rasoulifard, M. H. (2011). Homogeneous and heterogeneous AOPs for rapid degradation of Triton X-100 in aqueous media via UV light, nano titania hydrogen peroxide and potassium persulfate. Chemical Engineering Journal, 167(1), 172-182. http://dx.doi.org/10.1016/j.cej.2010.12.017

Saquib, M., Abu Tariq, M., Haque, M. M., \& Muneer, M. (2008). Photocatalytic degradation of disperse blue 1 using $\mathrm{UV} / \mathrm{TiO}_{2} / \mathrm{H}_{2} \mathrm{O}_{2}$ process. Journal of Environmental Management, 88(2), 300-306. http://dx.doi.org/10.1016/j.jenvman.2007.03.012

Stock, N. L., Peller, J., Vinodgopal, K., \& Kamat, P. V. (2000). Combinative sonolysis and photocatalysis for textile dye degradation. Environmental Science and Technology, 34(9), 1747-1750. http://dx.doi.org/ $10.1021 / \mathrm{es} 991231 \mathrm{c}$

Xiang, X., Xie, L., Li, Z., \& Li, F. (2013). Ternary $\mathrm{MgO} / \mathrm{ZnO} / \mathrm{In}_{2} \mathrm{O}_{3}$ heterostructured photocatalysts derived from a layered precursor and visible-light-induced photocatalytic activity. Chemical Engineering Journal, 221, 222-229. http://dx.doi.org/10.1016/j.cej.2013.02.030

Yang, Y., Wyatt Ii, D. T., \& Bahorsky, M. (1998). Decolorization of dyes using UV/ $\mathrm{H}_{2} \mathrm{O}_{2}$ photochemical oxidation. Textile Chemist and Colorist, 30(4), 27-35.

\section{Copyrights}

Copyright for this article is retained by the author(s), with first publication rights granted to the journal.

This is an open-access article distributed under the terms and conditions of the Creative Commons Attribution license (http://creativecommons.org/licenses/by/3.0/). 